\title{
Reconstitution of Female Germ Cell Fate Determination and Meiotic Initiation in Mammals
}

\author{
So I. NAGAOKA ${ }^{1,2}$ and Mitinori SAitou ${ }^{1,2,3,4}$ \\ ${ }^{1}$ Department of Anatomy and Cell Biology, Graduate School of Medicine, Kyoto University, \\ Yoshida-Konoe-cho, Sakyo-ku, Kyoto 606-8501, Japan \\ 2JST, ERATO, Yoshida-Konoe-cho, Sakyo-ku, Kyoto 606-8501, Japan \\ ${ }^{3}$ Center for iPS Cell Research and Application, Kyoto University, Shogoin, Sakyo-ku, \\ Kyoto 606-8507, Japan \\ ${ }^{4}$ Institute for Integrated Cell-Material Sciences, Kyoto University, Yoshida-Ushinomiya-cho, \\ Sakyo-ku, Kyoto 606-8501, Japan \\ Correspondence: saitou@anat2.med.kyoto-u.ac.jp
}

\begin{abstract}
Meiosis is a fundamental process that underpins sexual reproduction. In mammals, the execution of meiosis is tightly integrated within the complex processes of oogenesis and spermatogenesis, and elucidation of the molecular mechanisms regulating meiotic initiation remains challenging. We have recently developed in vitro culture strategies to induce mouse pluripotent stem cells into germ cells, which successfully contribute to both oogenesis and spermatogenesis and to fertile offspring. The culture strategies faithfully recapitulate transcriptional and epigenetic dynamics as well as signaling principles for germ cell specification, proliferation, and female sex determination/meiotic induction, providing a valuable platform for studies to illuminate the molecular mechanisms underlying such critical processes. Here, we review mammalian gametogenesis with a focus on the implementation of meiosis and, based on our recent studies, discuss new insights into the mechanisms for meiotic initiation and germ cell sex determination in mice.
\end{abstract}

For most eukaryotic lineages, the creation of haploid gametes through meiosis and fertilization constitutes the foundation for sexual reproduction that assures continual succession of life (Wilkins and Holliday 2009). Through evolution, the regulatory components for meiotic recombination and chromosome segregation have been highly conserved (Marston and Amon 2004; Handel and Schimenti 2010; Watanabe 2012; Baudat et al. 2013); however, the mechanisms controlling meiotic initiation are divergent and involve species-specific and sex-specific developmental contexts (Harigaya and Yamamoto 2007; Lesch and Page 2012). In mammals, the implementation of meiosis is embedded within the complex oogenesis and spermatogenesis processes, and elucidating the molecular mechanisms pertaining to meiotic initiation remains a challenge.

Recently, we devised strategies to successfully reconstitute germ cell specification pathways from pluripotent stem cells (embryonic stem cells [ESCs] and induced pluripotent stem cells [iPSCs]) in mice (Hayashi et al. 2011). The transcriptional and epigenetic constitution of the resultant germ cells closely resembles those of primordial germ cells (PGCs) (Hayashi et al. 2011; Ohta et al. 2017), a group of sexually uncommitted precursor cells that give rise to either oocytes or spermatozoa. Remarkably, the in vitro-derived PGCs (PGC-like cells [PGCLCs]) possess a robust capability to differentiate into functional oocytes and spermatozoa in mice and contribute to fertile offspring (Hayashi et al. 2011, 2012; Hikabe et al. 2016; Ishikura et al. 2016; Ohta et al. 2017). The establishment of robust in vitro germ cell derivation strategies presents unprecedented opportunities for studies to illuminate the mechanisms of epigenetic reprogramming, sex determination, and meiotic initiation during mammalian germ cell development (Kurimoto et al. 2015; Shirane et al. 2016; Miyauchi et al. 2017; Ohta et al. 2017). In this review, we highlight the key components of mammalian germ cell development, the current understanding of the mechanisms of sex determination and meiotic initiation, new findings emerging from the studies using PGCLCs, and outstanding areas of studies that await further investigation.

\section{GERM CELL SPECIFICATION IN MAMMALS}

In metazoan lineages, germ cell fate is conferred via two major mechanisms. In model organisms such as Drosophila melanogaster and Caenorhabditis elegans, the germ cell fate is specified by a mechanism called "preformation," in which the segregation and inheritance of maternal determinants from the egg specifies the future germ cell lineages in developing embryos (Extavour and Akam 2003). On the other hand, in mice and likely in other mammals, germ cell fate is specified by "epigenesis," in which pluripotent embryonic cells are induced to confer the germ cell fate through the actions of inductive and restrictive signals from surrounding tissues and the embryo itself (Extavour and Akam 2003; Saitou and Yamaji 2012). In mice, in which the mechanism has been exten-

(C) 2017 Nagaoka and Saitou. This article is distributed under the terms of the Creative Commons Attribution-NonCommercial License, which permits reuse and redistribution, except for commercial purposes, provided that the original author and source are credited. 
sively studied, the germ cell fate is induced in the most proximal posterior epiblast in response to bone morphogenic protein (BMP) signaling emanating from neighboring extraembryonic ectoderm tissues and WNT signaling from the proximal posterior epiblast itself, beginning at around embryonic day 5.5 (E5.5) (Lawson et al. 1999; Saitou et al. 2002; Ohinata et al. 2009). Inhibitory molecules of BMP signaling, such as CER1, are secreted from the anterior visceral endoderm and inhibit germ cell induction in the anterior epiblast, restricting the emergence of the germ cells in the posterior region of the epiblast (Perea-Gomez et al. 2002; Ohinata et al. 2009). Consequently, by E7.25, a cluster of 30-40 PGCs is established within the extraembryonic mesoderm at the base of the allantois, which constitutes the founding population of the germ cell lineages (Fig. 1; Ginsburg et al. 1990; Lawson et al. 1999; Saitou et al. 2002; Ohinata et al. 2009).

\section{SEX DETERMINATION AND MEIOTIC INITIATION IN MAMMALS}

After specification, PGCs migrate through the hindgut endoderm toward developing gonads. Concurrently with the completion of PGC migration, the embryonic gonads undergo sex determination and initiate sex-specific developmental programs based on their sex chromosome constitutions. In gonadal somatic cells in XY individuals, the expression of the sex determination gene on the Y chro- mosome, Sry, initiates the formation of testicular structures essential for spermatogenesis (Sinclair et al. 1990; Koopman et al. 1991; Brennan and Capel 2004; Eggers et al. 2014). On the other hand, in the absence of Sry, a concerted activation of several ovary-specification genes, such as Wnt4, Rspo1, and Foxl2, drives the development of ovaries (Brennan and Capel 2004; Eggers et al. 2014). Importantly, once the decision is made, networks of activating and repressing signals actively maintain the sexual fate of gonads into adulthood (Uhlenhaut et al. 2009; Matson et al. 2011; Capel 2017).

In contrast to the sex determination mechanisms of the gonadal somatic cells, for germ cells, the commitment to a particular sex is dependent on the surrounding environment regardless of their sex chromosome constitutions (McLaren 1984, 1988; Kimble and Page 2007; Spiller et al. 2017). Intriguingly, in the fetal gonads, sex determination is coupled with the decision to initiate meiotic programs (McLaren 1984, 1988; Kimble and Page 2007; Spiller et al. 2017). In fetal ovaries, after several rounds of mitotic divisions, germ cells (now called oogonia) initiate meiotic prophase. The implementation of chromosomal events of meiotic prophase marks the first visible divergence between female and male germ cells, and it is classically considered as the onset of oogenesis (Hilscher et al. 1974; Speed 1982; McLaren 1984, 1988; Kimble and Page 2007; Spiller et al. 2017). In fetal testes, on the other hand, germ cells (now called prospermatogonia or gonocytes) are actively suppressed from prematurely ini-

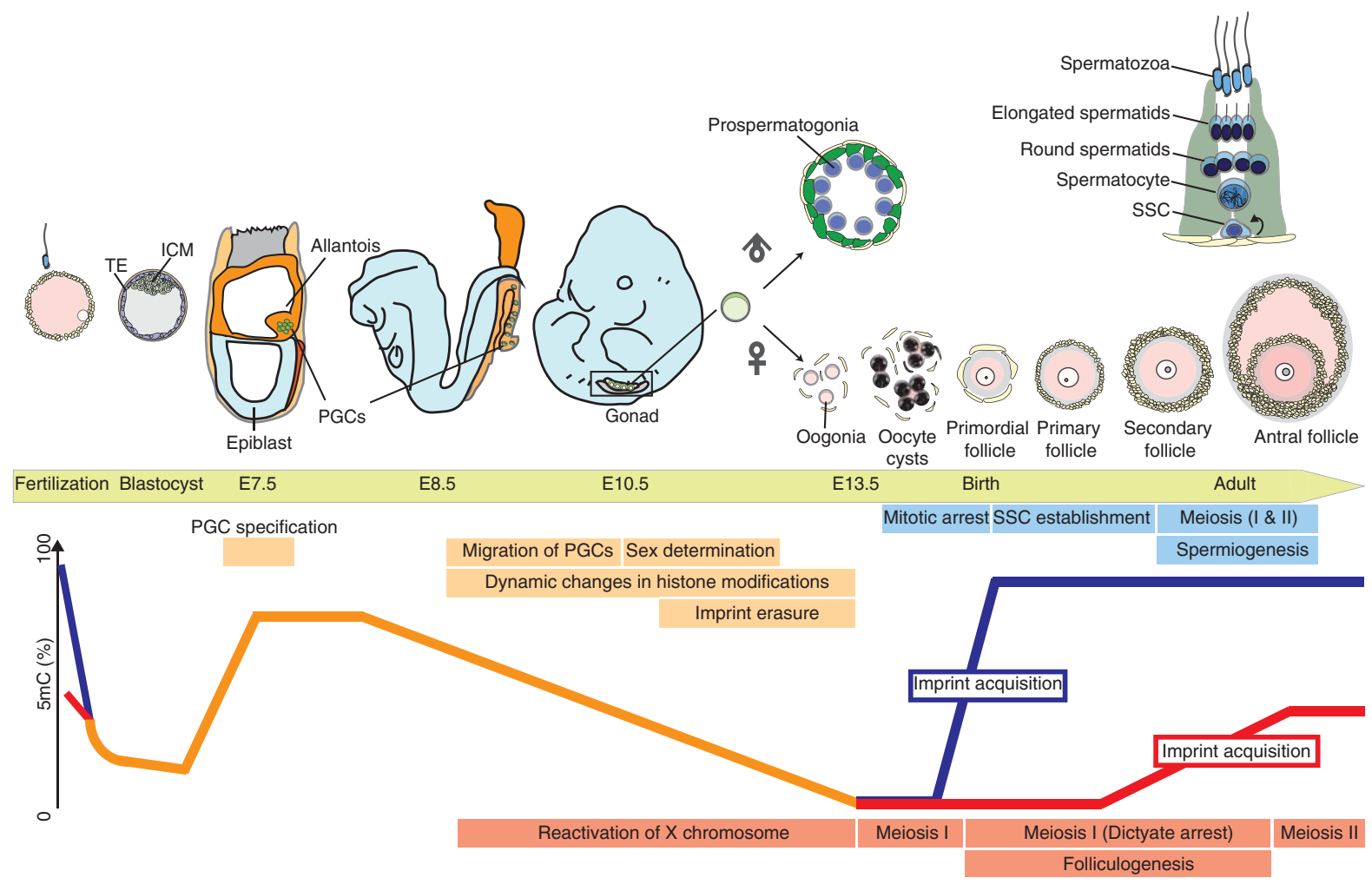

Figure 1. (Top) A schematic representation of germ cell development in mice. (Bottom) Key events associated with each stage of germ cell development are shown along with the dynamics of the $5 \mathrm{mC}$ levels. ICM, inner cell mass; TE, trophectoderm; SSC, spermatogonial stem cell; PGC, primordial germ cell. 
tiating meiosis, and this suppression appears critical for the commitment to the male germ cell pathway (Bowles et al. 2006; Koubova et al. 2006; MacLean et al. 2007; Saba et al. 2014b).

For the sexual commitment and meiotic induction, differential availability of retinoic acid (RA) between embryonic ovaries and testes is instrumental in setting up the sexually dimorphic development. RA is an active metabolite of vitamin A that is used in multiple developmental processes, including reproduction (Wilson et al. 1953; Huang and Hembree 1979; Morales and Griswold 1987; Niederreither and Dolle 2008; Li and Clagett-Dame 2009; Griswold et al. 2012; Cunningham and Duester 2015), and the actions of RA are controlled at the level of tissue distribution by the expressions of synthesizing and metabolizing enzymes and also at the molecular level by the actions of RA receptors and a cohort of interacting proteins (Bastien and Rochette-Egly 2004; Niederreither and Dolle 2008; Dolle 2009; Mark et al. 2009; Cunningham and Duester 2015). Developing gonads are capable of synthesizing RA (Bowles et al. 2016), but the predominant sites of RA synthesis appear to be at mesonephroi that develop adjacent to the gonads, with RA likely diffusing into gonads (Bowles et al. 2006; Koubova et al. 2006; Griswold et al. 2012; Feng et al. 2014).

In the germ cells of developing ovaries, the activation of RA signaling leads to the induction of meiotic genes and meiotic prophase (Baltus et al. 2006; Bowles et al. 2006; Koubova et al. 2006; MacLean et al. 2007; Le Bouffant et al. 2010; Childs et al. 2011; Saba et al. 2014b; Soh et al. 2015). Additionally, RA signaling suppresses the activation of several male germ cell specification genes (Bowles et al. 2010; Saba et al. 2014b), thus reinforcing the commencement of the female pathway. In male gonads, on the other hand, SRY and its immediate downstream target, SOX9, up-regulate the expression of CYP26B1, an enzyme that catabolizes RA (Kashimada et al. 2011; Li et al. 2014), thereby suppressing the onset of RA signaling and premature initiation of meiosis in the male germ cells (Bowles et al. 2006; Koubova et al. 2006; MacLean et al. 2007; Saba et al. 2014b). In addition to the suppression of the RA signaling, FGF9, secreted from Sertoli cells, as well as the expression of a translational regulator specific to male germ cells, NANOS2, promote the male germ cell pathway and repress the meiotic program (Suzuki and Saga 2008; Sada et al. 2009; Barrios et al. 2010; Bowles et al. 2010; Saba et al. 2014a; Kato et al. 2016). More recently, activin and nodal signaling have also been shown to reinforce the commitment to the male fate by activating Nanos 2 and other male germ cell genes as well as suppressing the induction of meiosis (Spiller et al. 2012; Wu et al. 2013, 2015).

\section{THE IMPLEMENTATION OF MEIOSIS DURING OOGENESIS AND SPERMATOGENESIS}

As discussed above, in females, oogonia initiate meiotic programs and begin meiotic prophase in fetal ovaries, and all the major chromosomal events of meiotic prophase-synapsis between homologous chromosomes, programmed DNA double-strand break formation, and formation of meiotic recombination-take place in the developing embryo (Gerton and Hawley 2005; Handel and Schimenti 2010; Baudat et al. 2013). Upon completion of the recombination processes, the oocyte enters the dictyate stage and the progression of meiosis becomes suspended (Fig. 1; Handel and Schimenti 2010). Concurrently, oocytes begin to establish intimate associations with surrounding granulosa cells and develop into primordial follicles (McGee and Hsueh 2000; Pepling and Spradling 2001; Matzuk et al. 2002; Li and Albertini 2013). The growth and maturation of the follicle take place postnatally, and intricate bidirectional signaling between the oocyte and granulosa cells is integral for successful folliculogenesis (Matzuk et al. 2002; Albertini 2015). During the growth, oocytes acquire maternal imprinting (Lucifero et al. 2002; Kobayashi et al. 2012) and undergo cytoplasmic maturation to establish the competence for fertilization and embryogenesis (Matzuk et al. 2002; Li and Albertini 2013). As the follicle completes its maturation, the surge of luteinizing hormone induces ovulation and releases the meiotic arrest. During the first meiotic division (also known as the reductional division), crossovers between homologous chromosomes, the product of meiotic recombination during the fetal stage, play a vital role in the segregation of homologous chromosomes (Gerton and Hawley 2005; Handel and Schimenti 2010; Nagaoka et al. 2012). Fertilization triggers the onset of second meiotic division and the production of a haploid egg (Handel and Schimenti 2010; Clift and Schuh 2013). Finally, the fusion between maternal and paternal pronuclei restores diploidy, and the life of a new individual begins. Thus, meiosis encompasses the entire duration of oogenesis in mammals, and intricate control mechanisms at various stages must be in place in order to coordinate the chromosomal events of meiosis and the execution of the developmental programs for generating a competent ovum.

In developing gonads of male embryos, prospermatogonia proliferate through several rounds of mitotic divisions, while actively suppressing the entry into meiosis (Bowles et al. 2006; Koubova et al. 2006; MacLean et al. 2007; Saba et al. 2014b). Subsequently, they enter into a quiescent state of $\mathrm{G}_{0} / \mathrm{G}_{1}$ mitotic arrest (Manku and Culty 2015; Spiller et al. 2017) and acquire androgenetic epigenome, including paternal imprints (Fig. 1; Davis et al. 2000; Ueda et al. 2000; Kato et al. 2007; Seisenberger et al. 2012; Kobayashi et al. 2013; Kubo et al. 2015). After birth, although many spermatogonia initiate the first wave of spermatogenesis in mice (Yoshida et al. 2006), a small pool establish a spermatogonial stem cell (SSC) population with a lifelong capacity to perform numerous rounds of spermatogenesis (Oatley and Brinster 2008; Yoshida 2012; Kanatsu-Shinohara and Shinohara 2013). At each round of spermatogenesis, SSCs give rise to differentiating spermatogonia, which undergo several rounds of mitotic cell divisions and then initiate meiosis (Griswold 2016). In contrast to meiosis in females, meiotic prophase and the two meiotic divisions in males proceed without a halt and result in the generation of four haploid spermatids (Fig. 1). Subsequently, spermatids un- 
dergo morphological transformation, as well as chromatin compaction in the form of histone-to-protamine replacement, and develop into highly motile and fertilizationcapable spermatozoa (Toshimori and Eddy 2015). Remarkably, throughout the seminiferous epithelium within the testes, new waves of spermatogenesis are constantly initiated from SSCs, which concurrently and successively mature to haploid spermatozoa, providing a continuous supply for the lifetime of a male (Griswold 2016).

Considering the integration of meiosis within sex-specific gametogenesis steps involving key functions of gonadal somatic cells, the establishment of experimental means that can resolve the intricate interactions between germ cells and somatic cells will be crucial for efforts to understand the mechanism for meiosis.

\section{IN VITRO DERIVATION OF PRIMORDIAL GERM CELLS}

The tantalizing capability of the germ cells to create new organisms has been inspiring developmental and stem cell biologists alike to attempt to recreate gametogenesis processes from pluripotent stem cells (Daley 2007; Saitou and Miyauchi 2016). In recent years, the realization of robust in vitro derivation strategies was finally achieved (Hayashi et al. 2011, 2012). This feat was largely attributable to the accumulation of knowledge about germ cell specification (Ginsburg et al. 1990; Lawson et al. 1999; Saitou et al. 2002; Ohinata et al. 2009), refined understanding of different pluripotent states among stem cells propagated in vitro (Hackett and Surani 2014; Martello and Smith 2014), and the development of reproductive technologies that can convincingly test the potency of the derived germ cells (Brinster and Avarbock 1994; Brinster and Zimmermann 1994; Chuma et al. 2005). The successful derivation strategies generate germ cells that closely resemble PGCs in their transcriptional and epigenetic characteristics. Importantly, the derived PGCLCs possess a robust capability to perform successful oogenesis and spermatogenesis that contribute to fertile offspring when transplanted into surrogate animals (for spermatogenesis and oogenesis) (Hayashi et al. 2011, 2012; Ishikura et al. 2016; Ohta et al. 2017) or when cultured in appropriate in vitro growth (IVG) and in vitro maturation (IVM) conditions (for oogenesis) (Fig. 2; Hikabe et al. 2016; Morohaku et al. 2016). Thus, the in vitro germ cell derivation strategy provides a valuable platform for studies to elucidate mechanisms underlying critical processes during mammalian germ cell development.

\section{EXPANSION CULTURE OF PGCs/PGCLCs AND RECONSTITUTION OF THE EPIGENETIC BLANK SLATE OF THE GERM CELLS}

Coculturing strategies with embryonic gonadal somatic cells are instructive in promoting the sex determination of PGCLCs and their differentiation toward oocytes or spermatogonia; however, the complexity of germ-soma interaction precludes the elucidation of the precise molecular mechanisms underlying sex determination. To overcome this obstacle, we have recently developed a culturing system to propagate sexually uncommitted PGCs/PGCLCs without the use of gonadal somatic cells (Ohta et al. 2017). By using the PGCLC system, we conducted systematic chemical screenings to identify compounds that can enhance the proliferative capacity of PGCs/PGCLCs. The screening revealed that cyclic AMP signaling plays a pivotal role in the expansion of PGCs/PGCLCs in culture, as previous studies reported using isolated PGCs (De Felici et al. 1993; Farini et al. 2005). Global transcriptome and cell cycle kinetics of the expanded PGCLCs showed that they maintained characteristics of sexually uncommitted PGCs. Importantly, functional testing upon transplantation into neonatal testes showed their robust capability to contribute to spermatogenesis. The proliferation of PGCLCs was accompanied with a steady decrease in global 5-methylcytosine $(5 \mathrm{mC})$ level, presumably driven by progressive dilution of methylation upon DNA replication (Seisenberger et al. 2012; Kagiwada et al. 2013; Kobayashi et al. 2013). At the end of the expansion culture, the global $5 \mathrm{mC}$ level of the PGCLCs was comparable to that of gonadal germ cells at E13.5 in mice, a stage at which the genome-wide DNA methylation level reaches its nadir during the germline cycle (Fig. 1; Seisenberger et al. 2012; Kobayashi et al. 2013). It is notable that the demethylation process showed differential kinetics at distinct genomic regions (i.e., promoters of demethylationresistant "germline genes," ICRs of imprinted genes, and repetitive elements), in a manner reminiscent of PGCs (Seisenberger et al. 2012; Kobayashi et al. 2013). Further, we found that "escapees" that evade DNA demethylation $(5 \mathrm{mC}>20 \%)$ during PGCLC derivation and the expansion culture largely overlapped with those found in E13.5 germ cells (Seisenberger et al. 2012; Ohta et al. 2017). Thus, the induction of PGCLCs and subsequent expansion culture recapitulated the DNA methylation reprogramming events of PGCs. Remarkably, this global hypomethylation state was accompanied by apparent upregulation of histone $\mathrm{H} 3 \mathrm{~K} 27 \mathrm{me} 3$ at promoters of genes that showed substantial demethylation during the expansion culture, plausibly compensating for the hypomethylation state and preventing aberrant gene expression from such loci. Nonetheless, we observed a partial activation of key gonadal germ cell genes that took place concurrently with the erasure of DNA methylation and reorganization of the histone modification landscape, implying that such epigenetic reorganization leads to a basal activation of some germline genes and might prime the germ cells for the eventual reception of the sex determination signals (Ohta et al. 2017). Taken together, these findings show that expansion culture recapitulates a global epigenetic reorganization process that forms an epigenetic "blank slate" of the germ cells upon which either an androgenetic or a gynogenetic epigenome can be established. The global epigenetic reorganization in the PGCs occurs cell-autonomously, without the guidance from gonadal somatic cells, and thus the reorganization process is an event genetically dissociable from the germ cell sex determination program. 


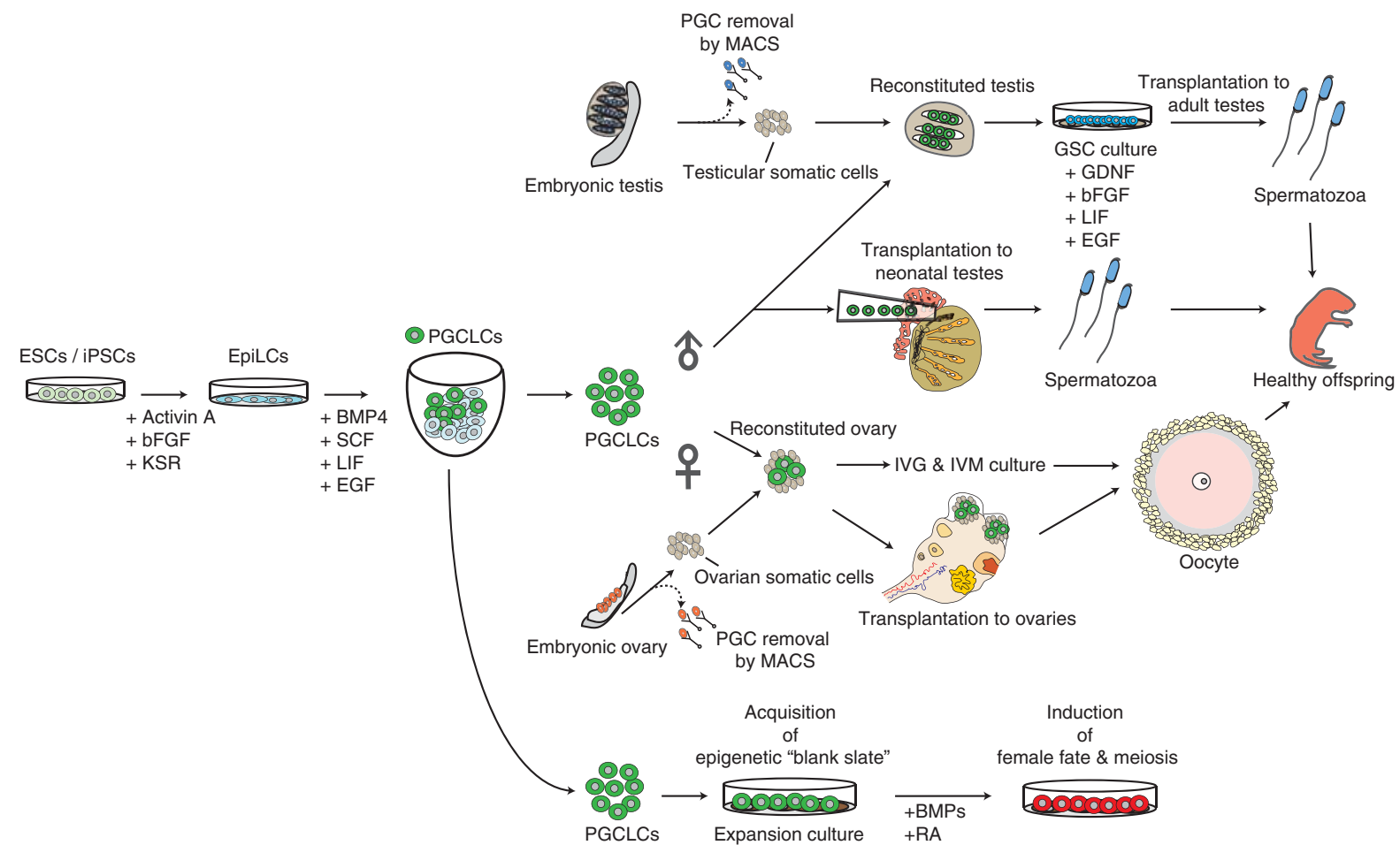

Figure 2. A schematic drawing of the methodologies for mouse germ cell derivation and development from pluripotent stem cells. Embryonic stem cells (ESCs) and induced pluripotent stem cells (iPSCs) cultured under a 2i+LIF condition are induced to epiblast-like cells (EpiLCs). EpiLCs are then induced into primordial germ cell (PGC)-like cells (PGCLCs) in floating aggregates. PGCLCs transplanted into neonatal testes will commit to the male pathway and undergo spermatogenesis successfully (Hayashi et al. 2011). PGCLCs cocultured with embryonic ovarian somatic cells (Reconstituted ovary) commit to the female fate and, upon transplantation to adult ovaries, develop to fertilization-competent oocytes (Hayashi et al. 2012). Alternatively, the reconstituted ovaries can be cultured under appropriate in vitro growth (IVG) and in vitro maturation (IVM) conditions to foster development into competent oocytes completely in vitro (Hikabe et al. 2016). PGCLCs cocultured with embryonic testicular somatic cells (Reconstituted testis) commit to the male fate and differentiate to spermatogonia, which can be subsequently propagated to establish male germline stem cell (GSC) lines that contribute to spermatogenesis upon transplantation to adult testes (Ishikura et al. 2016). PGCLCs propagated in vitro (Expansion culture) maintain a sexually uncommitted state and acquire an epigenetic "blank slate" (Ohta et al. 2017). Subsequently they can be induced to confer the female fate and initiate meiosis upon bone morphogenic protein (BMP) and retinoic acid (RA) treatment (Miyauchi et al. 2017). MACS, magnetic activated cell sorting.

\section{SIGNALING PRINCIPLES FOR FEMALE GERM CELL SEX DETERMINATION AND MEIOTIC INDUCTION}

The PGCLC expansion system described above, in which the sexual fate of the germ cells remains uncommitted, provides a valuable platform for studies to reconstitute the processes of germ cell sex determination and meiotic initiation. Using this culture system, we examined the effects of a panel of cytokines that might have an impact on sex determination with or without the treatment of RA (Miyauchi et al. 2017). Among the combinations of molecules we assayed, the combined provision of BMPs and RA resulted in the up-regulation of transcriptional programs for oogenesis and initiation of meiotic prophase. Notably, the transcriptional and cytological progression faithfully recapitulated the events of fetal oocytes, and the initiation of meiosis occurred in a highly synchronous manner within germ cell cysts (Miyauchi et al. 2017), demonstrating a coordinated developmental progress within the oocyte cysts (Fig. 1; Pepling and Spradling 1998). It has previously been shown that developing em- bryonic ovaries strongly express $B m p$ genes, particularly Bmp2 under the influence of Wnt4 (Yao et al. 2004; Ross et al. 2007; Jameson et al. 2012), and germ cell-specific deletion of Smad4, a gene coding for an essential signal transducer of BMP/TGF $\beta$ signaling, negatively affects the induction of female germ cell fate and meiotic onset $(\mathrm{Wu}$ et al. 2016). When considered together with our current results and those of other groups (Farini et al. 2005), these findings clearly show that BMP signaling plays a pivotal role in the induction of female germ cell fate. To our surprise, although RA signaling was proved to be essential for meiotic induction and oogenesis commitment, the addition of RA alone was not sufficient to confer the female fate (Miyauchi et al. 2017). Specifically, treatment with RA alone resulted in the up-regulation of known RA-regulated genes that are involved in meiosis (i.e., Stra8 and Rec8) (Oulad-Abdelghani et al. 1996; Mahony et al. 2011; Koubova et al. 2014; Soh et al. 2015), but the activation of these genes was not sufficient to initiate meiosis. Instead, the RA-only treatment up-regulated genes involved in other developmental programs (e.g., "embryonic organ development"), indicating that the cross talk with BMP 
signaling is essential not only to activate the transcriptional cascades for the induction of meiosis and oogenic programs but also to repress inappropriate developmental programs elicited by RA. In the absence of Stra8, a gene essential for premeiotic DNA replication, combined treatment of BMP and RA failed to fully activate meiotic genes and to repress unnecessary developmental programs (Miyauchi et al. 2017). Notably, however, Stra8 knockout did not prevent the activation of many fetal oocyte genes, including those involved in oocyte development (e.g., Figla and Sohlh2), demonstrating that the oocyte developmental program is independent from STRA8 and the chromosomal events of meiotic prophase, as reported recently (Dokshin et al. 2013).

During the expansion culture, PGCLCs globally erase $5 \mathrm{mC}$ in a comprehensive manner to a level comparable to E13.5 germ cells in mice (Ohta et al. 2017), a stage immediately preceding meiotic onset in females, and we tested whether such epigenetic states play a permissive role in sex determination and meiotic initiation. The combined BMP and RA treatment failed to induce meiotic genes in PGCLCs immediately after the inception from epiblast-like cells, but the treatment resulted in a robust activation of meiotic genes and commitment to the female fate after PGCLCs completed epigenetic reprogramming, indicating that the global epigenetic changes might make the germ cells more receptive to signals for sex determination and initiation of meiosis (Miyauchi et al. 2017). Interestingly, spermatogonia undergo significant DNA demethylation at promoters of relevant meiotic genes be- fore meiotic initiation (Kubo et al. 2015; Miyauchi et al. 2017). This demethylation occurs despite the global reacquisition of high $5 \mathrm{mC}$ level during male germ cell development (Fig. 1; Kubo et al. 2015), implying that epigenetic requirements for meiotic entry might be common between male and female germ cells (Miyauchi et al. 2017). Such competence acquisition could be partly explained by the erasure of DNA methylation marks at promoters of key germ cell genes (e.g., Dazl). An evolutionary conserved RNA binding protein, DAZL, has been shown to be a critical factor for sexual commitment and meiotic initiation in mice (although the influence of DAZL in sex determination and meiotic initiation varies among different genetic backgrounds) (Ruggiu et al. 1997; Lin et al. 2008; Gill et al. 2011). In our work, the reduction of $5 \mathrm{mC}$ level at Dazl promoter was accompanied by a basal activation of Dazl during the expansion culture, which likely contributed to the competence acquisition and thus to the commitment to the female germ cell fate upon activation of RA and BMP signaling (Lin et al. 2008; Gill et al. 2011; Kato et al. 2016; Miyauchi et al. 2017). Collectively, our works show that meiotic initiation requires a delicate coupling between extrinsic inputs and intrinsic molecular circuitry within the germ cell: Germ cell-autonomous epigenetic remodeling is instrumental in initiating the meiotic program and also in inducing female fate upon concerted activation of BMP and RA signaling (Fig. 3). Elucidation of downstream effector(s) of BMP signaling and investigation of the mechanisms by which BMP signaling, in concert with RA signaling, orchestrates

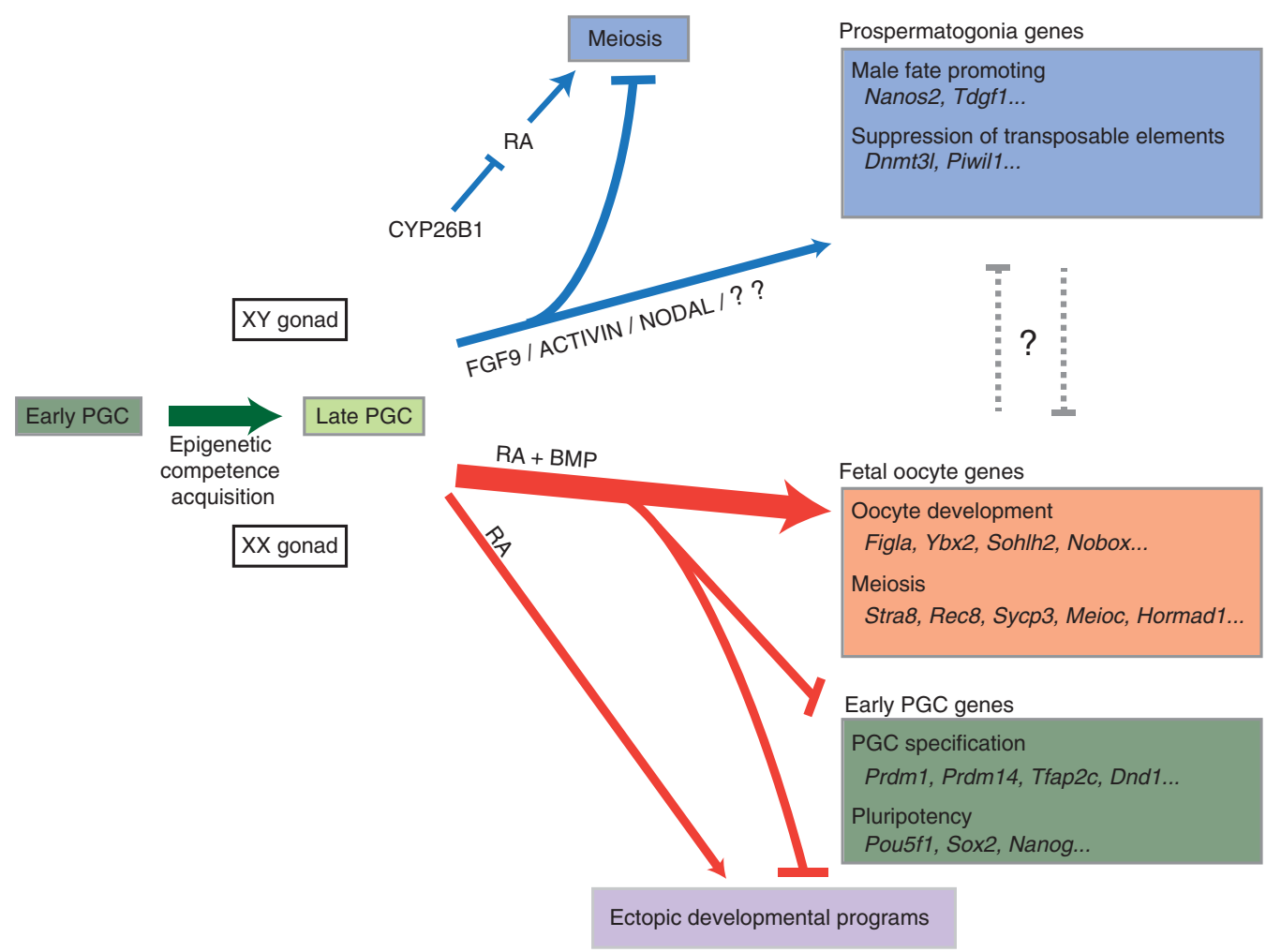

Figure 3. A schematic representation of a potential signaling network controlling the sex determination processes for germ cells. 
the onset of female fate and meiotic initiation will be key challenges for the future.

Interestingly, a recent report showed that PGCLCs can initiate meiosis and develop into spermatid-like cells if cocultured with dissociated testicular cells of neonatal mice in the presence of RA, BMP2/4/7, and activin A for 6 days, followed by treatments of follicle stimulating hormone, bovine pituitary extract, and testosterone in the subsequent 8 days (Zhou et al. 2016). Surprisingly, the reported "in vitro spermatogenesis" procedure skips a period of more than 2 weeks of male germ cell development in vivo - that is, the period from PGCs at around E9.5 to spermatogonia before meiotic onset at postnatal day 10 (Bellvé et al. 1977). It is important to note that, during this period, male germ cells undergo epigenetic reprogramming, acquire the androgenetic epigenome, and differentiate into spermatogonia (Davis et al. 2000; Ueda et al. 2000; Kato et al. 2007; Seisenberger et al. 2012; Kobayashi et al. 2013; Kubo et al. 2015; Manku and Culty 2015). Furthermore, the reported procedure was conducted entirely at $37^{\circ} \mathrm{C}$, a nonpermissive temperature for spermatogenesis (Steinberger et al. 1964; Sato et al. 2011). Thus, we consider it important to re-examine the validity of this study, including a precise analysis of the induced intermediate cells.

\section{CONCLUSION}

In this review, we have provided a brief outline of mammalian germ cell development with a focus on the implementation of meiosis and the latest findings from in vitro germ cell derivation studies. Meiosis is a process that is conserved from unicellular organisms to multicellular organisms, and species-specific gametogenic strategies have evolved for successful execution of meiosis (Harigaya and Yamamoto 2007; Lesch and Page 2012). Recent advances have begun to provide a blueprint of how mammals execute meiosis in the context of epigenetic (Yokobayashi et al. 2013; Miyauchi et al. 2017), transcriptional (Soh et al. 2015; Miyauchi et al. 2017), extracellular signaling (Bowles et al. 2006; Koubova et al. 2006; MacLean et al. 2007; Saba et al. 2014b; Miyauchi et al. 2017), and posttranscriptional regulations (Zheng et al. 2013; Abby et al. 2016; Kato et al. 2016; Hsu et al. 2017; Soh et al. 2017). Moving forward, considering our rudimentary understanding of how sex determination and meiotic onset are coupled in the fetal gonads (Hilscher et al. 1974; McLaren 1984, 1988; Kimble and Page 2007; Spiller et al. 2017), elucidation of the molecular interweaving between these processes will be imperative. Moreover, future studies should aim to address how germ cells commit to the male pathway and establish spermatogonial stem cell molecular circuitry while maintaining the potential for meiosis. Considering the tight integration of meiosis within the intricate oogenesis and spermatogenesis processes, a deeper understanding of the interactions with the surrounding somatic cells will surely hold the key in the coming years. Last, the recent advent of germ cell derivation strategies from human pluripotent stem cells (Irie et al. 2015; Sasaki et al. 2015), elucidation of the cellular origins of primordial germ cells and molecular signatures defining distinct cell types of peri-implantation primate embryos (Nakamura et al. 2016; Sasaki et al. 2016), and investigations of transcriptome and epigenome characteristics of human germ cells during embryonic development (Gkountela et al. 2015; Guo et al. 2015; Tang et al. 2015; Li et al. 2017) have laid the groundwork for future efforts at the reconstitution of human gametogenesis. If successful, such reconstitution would provide valuable insights into the mechanism of human germ cell development and into the causes of anomalies that hamper human reproduction (Handel and Schimenti 2010; Nagaoka et al. 2012).

\section{ACKNOWLEDGMENTS}

We thank H. Ohta, H. Miyauchi, and the members of our laboratory for their discussion and suggestions. The authors were supported in part by a Japan Society for the Promotion of Science (JSPS) Research Fellowship for Young Scientists to S.I.N., by funds from Japan Science and Technology Agency Exploratory Research for Advanced Technology (JST-ERATO) to M.S. (JPMJER1104), and by a Grant-in-Aid for Specially Promoted Research from JSPS to M.S. (17H06098).

\section{REFERENCES}

Abby E, Tourpin S, Ribeiro J, Daniel K, Messiaen S, Moison D, Guerquin J, Gaillard JC, Armengaud J, Langa F, et al. 2016. Implementation of meiosis prophase I programme requires a conserved retinoid-independent stabilizer of meiotic transcripts. Nat Commun 7: 10324.

Albertini DF. 2015. The mammalian oocyte. In Knobil and Neill's physiology of reproduction (eds. Plant TM, Zeleznik AJ, Albertini DF, et al.), pp. 59-97. Elsevier/Academic, New York.

Baltus AE, Menke DB, Hu YC, Goodheart ML, Carpenter AE, de Rooij DG, Page DC. 2006. In germ cells of mouse embryonic ovaries, the decision to enter meiosis precedes premeiotic DNA replication. Nat Genet 38: 1430-1434.

Barrios F, Filipponi D, Pellegrini M, Paronetto MP, Di Siena S, Geremia R, Rossi P, De Felici M, Jannini EA, Dolci S. 2010. Opposing effects of retinoic acid and FGF9 on Nanos2 expression and meiotic entry of mouse germ cells. J Cell Sci 123: 871-880.

Bastien J, Rochette-Egly C. 2004. Nuclear retinoid receptors and the transcription of retinoid-target genes. Gene 328: 1-16.

Baudat F, Imai Y, de Massy B. 2013. Meiotic recombination in mammals: Localization and regulation. Nat Rev Genet 14: 794-806.

Bellvé AR, Cavicchia JC, Millette CF, O'Brien DA, Bhatnagar YM, Dym M. 1977. Spermatogenic cells of the prepuberal mouse. Isolation and morphological characterization. J Cell Biol 74: 68-85.

Bowles J, Knight D, Smith C, Wilhelm D, Richman J, Mamiya S, Yashiro K, Chawengsaksophak K, Wilson MJ, Rossant J, et al. 2006. Retinoid signaling determines germ cell fate in mice. Science 312: 596-600.

Bowles J, Feng CW, Spiller C, Davidson TL, Jackson A, Koopman P. 2010. FGF9 suppresses meiosis and promotes male germ cell fate in mice. Dev Cell 19: 440-449.

Bowles J, Feng CW, Miles K, Ineson J, Spiller C, Koopman P. 2016. ALDH1A1 provides a source of meiosis-inducing retinoic acid in mouse fetal ovaries. Nat Commun 7: 10845.

Brennan J, Capel B. 2004. One tissue, two fates: Molecular genetic events that underlie testis versus ovary development. Nat Rev Genet 5: 509-521. 
Brinster RL, Avarbock MR. 1994. Germline transmission of donor haplotype following spermatogonial transplantation. Proc Natl Acad Sci 91: 11303-11307.

Brinster RL, Zimmermann JW. 1994. Spermatogenesis following male germ-cell transplantation. Proc Natl Acad Sci 91: 1129811302 .

Capel B. 2017. Vertebrate sex determination: Evolutionary plasticity of a fundamental switch. Nat Rev Genet. doi: 10.1038/ nrg.2017.60.

Childs AJ, Cowan G, Kinnell HL, Anderson RA, Saunders PT. 2011. Retinoic acid signalling and the control of meiotic entry in the human fetal gonad. PLoS One 6: e20249.

Chuma S, Kanatsu-Shinohara M, Inoue K, Ogonuki N, Miki H, Toyokuni S, Hosokawa M, Nakatsuji N, Ogura A, Shinohara T. 2005. Spermatogenesis from epiblast and primordial germ cells following transplantation into postnatal mouse testis. Development 132: 117-122.

Clift D, Schuh M. 2013. Restarting life: Fertilization and the transition from meiosis to mitosis. Nat Rev Mol Cell Biol 14: 549-562.

Cunningham TJ, Duester G. 2015. Mechanisms of retinoic acid signalling and its roles in organ and limb development. Nat Rev Mol Cell Biol 16: 110-123.

Daley GQ. 2007. Gametes from embryonic stem cells: A cup half empty or half full? Science 316: 409-410.

Davis TL, Yang GJ, McCarrey JR, Bartolomei MS. 2000. The H19 methylation imprint is erased and re-established differentially on the parental alleles during male germ cell development. Hum Mol Genet 9: 2885-2894.

De Felici M, Dolci S, Pesce M. 1993. Proliferation of mouse primordial germ cells in vitro: A key role for cAMP. Dev Biol 157: 277-280.

Dokshin GA, Baltus AE, Eppig JJ, Page DC. 2013. Oocyte differentiation is genetically dissociable from meiosis in mice. Nat Genet 45: 877-883.

Dolle P. 2009. Developmental expression of retinoic acid receptors (RARs). Nucl Recept Signal 7: e006.

Eggers S, Ohnesorg T, Sinclair A. 2014. Genetic regulation of mammalian gonad development. Nat Rev Endocrinol 10: 673683.

Extavour CG, Akam M. 2003. Mechanisms of germ cell specification across the metazoans: Epigenesis and preformation. Development 130: 5869-5884.

Farini D, Scaldaferri ML, Iona S, La Sala G, De Felici M. 2005. Growth factors sustain primordial germ cell survival, proliferation and entering into meiosis in the absence of somatic cells. Dev Biol 285: 49-56.

Feng CW, Bowles J, Koopman P. 2014. Control of mammalian germ cell entry into meiosis. Mol Cell Endocrinol 382: 488497.

Gerton JL, Hawley RS. 2005. Homologous chromosome interactions in meiosis: Diversity amidst conservation. Nat Rev Genet 6: 477-487.

Gill ME, Hu YC, Lin Y, Page DC. 2011. Licensing of gametogenesis, dependent on RNA binding protein DAZL, as a gateway to sexual differentiation of fetal germ cells. Proc Natl Acad Sci 108: 7443-7448.

Ginsburg M, Snow MH, McLaren A. 1990. Primordial germ cells in the mouse embryo during gastrulation. Development 110: $521-528$.

Gkountela S, Zhang KX, Shafiq TA, Liao WW, Hargan-Calvopiña J, Chen PY, Clark AT. 2015. DNA demethylation dynamics in the human prenatal germline. Cell 161: 1425-1436.

Griswold MD. 2016. Spermatogenesis: The commitment to meiosis. Physiol Rev 96: 1-17.

Griswold MD, Hogarth CA, Bowles J, Koopman P. 2012. Initiating meiosis: The case for retinoic acid. Biol Reprod 86: 35.

Guo F, Yan L, Guo H, Li L, Hu B, Zhao Y, Yong J, Hu Y, Wang X, Wei Y et al. 2015. The transcriptome and DNA methylome landscapes of human primordial germ cells. Cell 161: 14371452.

Hackett JA, Surani MA. 2014. Regulatory principles of pluripotency: From the ground state up. Cell Stem Cell 15: 416-430.
Handel MA, Schimenti JC. 2010. Genetics of mammalian meiosis: Regulation, dynamics and impact on fertility. Nat Rev Genet 11: 124-136.

Harigaya Y, Yamamoto M. 2007. Molecular mechanisms underlying the mitosis-meiosis decision. Chromosome Res 15: 523-537.

Hayashi K, Ohta H, Kurimoto K, Aramaki S, Saitou M. 2011. Reconstitution of the mouse germ cell specification pathway in culture by pluripotent stem cells. Cell 146: 519-532.

Hayashi K, Ogushi S, Kurimoto K, Shimamoto S, Ohta H, Saitou M. 2012. Offspring from oocytes derived from in vitro primordial germ cell-like cells in mice. Science 338: 971975.

Hikabe O, Hamazaki N, Nagamatsu G, Obata Y, Hirao Y, Hamada N, Shimamoto S, Imamura T, Nakashima K, Saitou M, et al. 2016. Reconstitution in vitro of the entire cycle of the mouse female germ line. Nature 539: 299-303.

Hilscher B, Hilscher W, Bülthoff-Ohnolz B, Krämer U, Birke A, Pelzer H, Gauss G. 1974. Kinetics of gametogenesis. I. Comparative histological and autoradiographic studies of oocytes and transitional prospermatogonia during oogenesis and prespermatogenesis. Cell Tissue Res 154: 443-470.

Hsu PJ, Zhu Y, Ma H, Guo Y, Shi X, Liu Y, Qi M, Lu Z, Shi H, Wang J, et al. 2017. Ythdc2 is an N6-methyladenosine binding protein that regulates mammalian spermatogenesis. Cell Res 27: 1115-1127.

Huang HF, Hembree WC. 1979. Spermatogenic response to vitamin A in vitamin A deficient rats. Biol Reprod 21: 891-904.

Irie N, Weinberger L, Tang WW, Kobayashi T, Viukov S, Manor YS, Dietmann S, Hanna JH, Surani MA. 2015. SOX17 is a critical specifier of human primordial germ cell fate. Cell 160: 253-268.

Ishikura Y, Yabuta Y, Ohta H, Hayashi K, Nakamura T, Okamoto I, Yamamoto T, Kurimoto K, Shirane K, Sasaki H, et al. 2016. In vitro derivation and propagation of spermatogonial stem cell activity from mouse pluripotent stem cells. Cell Rep 17: 27892804.

Jameson SA, Natarajan A, Cool J, DeFalco T, Maatouk DM, Mork L, Munger SC, Capel B. 2012. Temporal transcriptional profiling of somatic and germ cells reveals biased lineage priming of sexual fate in the fetal mouse gonad. PLoS Genet 8: e1002575.

Kagiwada S, Kurimoto K, Hirota T, Yamaji M, Saitou M. 2013. Replication-coupled passive DNA demethylation for the erasure of genome imprints in mice. EMBO J 32: 340-353.

Kanatsu-Shinohara M, Shinohara T. 2013. Spermatogonial stem cell self-renewal and development. Annu Rev Cell Dev Biol 29: 163-187.

Kashimada K, Svingen T, Feng CW, Pelosi E, Bagheri-Fam S, Harley VR, Schlessinger D, Bowles J, Koopman P. 2011. Antagonistic regulation of Cyp26b1 by transcription factors SOX9/SF1 and FOXL2 during gonadal development in mice. FASEB J 25: 3561-3569.

Kato Y, Kaneda M, Hata K, Kumaki K, Hisano M, Kohara Y, Okano M, Li E, Nozaki M, Sasaki H. 2007. Role of the Dnmt3 family in de novo methylation of imprinted and repetitive sequences during male germ cell development in the mouse. Hum Mol Genet 16: 2272-2280.

Kato Y, Katsuki T, Kokubo H, Masuda A, Saga Y. 2016. Dazl is a target RNA suppressed by mammalian NANOS2 in sexually differentiating male germ cells. Nat Commun 7: 11272.

Kimble J, Page DC. 2007. The mysteries of sexual identity. The germ cell's perspective. Science 316: 400-401.

Kobayashi H, Sakurai T, Imai M, Takahashi N, Fukuda A, Yayoi O, Sato S, Nakabayashi K, Hata K, Sotomaru Y, et al. 2012. Contribution of intragenic DNA methylation in mouse gametic DNA methylomes to establish oocyte-specific heritable marks. PLoS Genet 8: e1002440.

Kobayashi H, Sakurai T, Miura F, Imai M, Mochiduki K, Yanagisawa E, Sakashita A, Wakai T, Suzuki Y, Ito T, et al. 2013. High-resolution DNA methylome analysis of primordial germ cells identifies gender-specific reprogramming in mice. $\mathrm{Ge}$ nome Res 23: 616-627. 
Koopman P, Gubbay J, Vivian N, Goodfellow P, Lovell-Badge R. 1991. Male development of chromosomally female mice transgenic for Sry. Nature 351: 117-121.

Koubova J, Menke DB, Zhou Q, Capel B, Griswold MD, Page DC. 2006. Retinoic acid regulates sex-specific timing of meiotic initiation in mice. Proc Natl Acad Sci 103: 24742479.

Koubova J, Hu YC, Bhattacharyya T, Soh YQ, Gill ME, Goodheart ML, Hogarth CA, Griswold MD, Page DC. 2014. Retinoic acid activates two pathways required for meiosis in mice. PLoS Genet 10: e1004541.

Kubo N, Toh H, Shirane K, Shirakawa T, Kobayashi H, Sato T, Sone H, Sato Y, Tomizawa S, Tsurusaki Y, et al. 2015. DNA methylation and gene expression dynamics during spermatogonial stem cell differentiation in the early postnatal mouse testis. BMC Genomics 16: 624.

Kurimoto K, Yabuta Y, Hayashi K, Ohta H, Kiyonari H, Mitani T, Moritoki Y, Kohri K, Kimura H, Yamamoto T, et al. 2015. Quantitative dynamics of chromatin remodeling during germ cell specification from mouse embryonic stem cells. Cell Stem Cell 16: 517-532.

Lawson KA, Dunn NR, Roelen BA, Zeinstra LM, Davis AM, Wright CV, Korving JP, Hogan BL. 1999. Bmp4 is required for the generation of primordial germ cells in the mouse embryo. Genes Dev 13: 424-436.

Le Bouffant R, Guerquin MJ, Duquenne C, Frydman N, Coffigny $\mathrm{H}$, Rouiller-Fabre V, Frydman R, Habert R, Livera G. 2010. Meiosis initiation in the human ovary requires intrinsic retinoic acid synthesis. Hum Reprod 25: 2579-2590.

Lesch BJ, Page DC. 2012. Genetics of germ cell development. Nat Rev Genet 13: 781-794.

Li R, Albertini DF. 2013. The road to maturation: Somatic cell interaction and self-organization of the mammalian oocyte. Nat Rev Mol Cell Biol 14: 141-152.

Li H, Clagett-Dame M. 2009. Vitamin A deficiency blocks the initiation of meiosis of germ cells in the developing rat ovary in vivo. Biol Reprod 81: 996-1001.

Li Y, Zheng M, Lau YF. 2014. The sex-determining factors SRY and SOX9 regulate similar target genes and promote testis cord formation during testicular differentiation. Cell Rep 8: 723 733.

Li L, Dong J, Yan L, Yong J, Liu X, Hu Y, Fan X, Wu X, Guo H, Wang X, et al. 2017. Single-cell RNA-seq analysis maps development of human germline cells and gonadal niche interactions. Cell Stem Cell 20: 891-892.

Lin Y, Gill ME, Koubova J, Page DC. 2008. Germ cell-intrinsic and -extrinsic factors govern meiotic initiation in mouse embryos. Science 322: 1685-1687.

Lucifero D, Mertineit C, Clarke HJ, Bestor TH, Trasler JM. 2002. Methylation dynamics of imprinted genes in mouse germ cells. Genomics 79: 530-538.

MacLean G, Li H, Metzger D, Chambon P, Petkovich M. 2007. Apoptotic extinction of germ cells in testes of Cyp26b1 knockout mice. Endocrinology 148: 4560-4567.

Mahony S, Mazzoni EO, McCuine S, Young RA, Wichterle H, Gifford DK. 2011. Ligand-dependent dynamics of retinoic acid receptor binding during early neurogenesis. Genome Biol 12: R2

Manku G, Culty M. 2015. Mammalian gonocyte and spermatogonia differentiation: Recent advances and remaining challenges. Reproduction 149: R139-R157.

Mark M, Ghyselinck NB, Chambon P. 2009. Function of retinoic acid receptors during embryonic development. Nucl Recept Signal 7: e002.

Marston AL, Amon A. 2004. Meiosis: Cell-cycle controls shuffle and deal. Nat Rev Mol Cell Biol 5: 983-997.

Martello G, Smith A. 2014. The nature of embryonic stem cells. Annu Rev Cell Dev Biol 30: 647-675.

Matson CK, Murphy MW, Sarver AL, Griswold MD, Bardwell VJ, Zarkower D. 2011. DMRT1 prevents female reprogramming in the postnatal mammalian testis. Nature 476: 101-104.
Matzuk MM, Burns KH, Viveiros MM, Eppig JJ. 2002. Intercellular communication in the mammalian ovary: Oocytes carry the conversation. Science 296: 2178-2180.

McGee EA, Hsueh AJ. 2000. Initial and cyclic recruitment of ovarian follicles. Endocr Rev 21: 200-214.

McLaren A. 1984. Meiosis and differentiation of mouse germ cells. Symp Soc Exp Biol 38: 7-23.

McLaren A. 1988. Somatic and germ-cell sex in mammals. Philos Trans R Soc Lond B Biol Sci 322: 3-9.

Miyauchi H, Ohta H, Nagaoka S, Nakaki F, Sasaki K, Hayashi K, Yabuta Y, Nakamura T, Yamamoto T, Saitou M. 2017. Bone morphogenetic protein and retinoic acid synergistically specify female germ-cell fate in mice. EMBO J. doi: 10.15252/ embj. 201796875.

Morales C, Griswold MD. 1987. Retinol-induced stage synchronization in seminiferous tubules of the rat. Endocrinology 121: 432-434.

Morohaku K, Tanimoto R, Sasaki K, Kawahara-Miki R, Kono T, Hayashi K, Hirao Y, Obata Y. 2016. Complete in vitro generation of fertile oocytes from mouse primordial germ cells. Proc Natl Acad Sci 113: 9021-9026.

Nagaoka SI, Hassold TJ, Hunt PA. 2012. Human aneuploidy: Mechanisms and new insights into an age-old problem. Nat Rev Genet 13: 493-504.

Nakamura T, Okamoto I, Sasaki K, Yabuta Y, Iwatani C, Tsuchiya H, Seita Y, Nakamura S, Yamamoto T, Saitou M. 2016. A developmental coordinate of pluripotency among mice, monkeys and humans. Nature 537: 57-62.

Niederreither K, Dolle P. 2008. Retinoic acid in development: Towards an integrated view. Nat Rev Genet 9: 541-553.

Oatley JM, Brinster RL. 2008. Regulation of spermatogonial stem cell self-renewal in mammals. Annu Rev Cell Dev Biol 24: $263-286$

Ohinata Y, Ohta H, Shigeta M, Yamanaka K, Wakayama T, Saitou M. 2009. A signaling principle for the specification of the germ cell lineage in mice. Cell 137: 571-584.

Ohta H, Kurimoto K, Okamoto I, Nakamura T, Yabuta Y, Miyauchi H, Yamamoto T, Okuno Y, Hagiwara M, Shirane K, et al. 2017. In vitro expansion of mouse primordial germ cell-like cells recapitulates an epigenetic blank slate. $E M B O J \mathbf{3 6}$ : $1888-1907$.

Oulad-Abdelghani M, Bouillet P, Decimo D, Gansmuller A, Heyberger S, Dolle P, Bronner S, Lutz Y, Chambon P. 1996. Characterization of a premeiotic germ cell-specific cytoplasmic protein encoded by Stra8, a novel retinoic acid-responsive gene. J Cell Biol 135: 469-477.

Pepling ME, Spradling AC. 1998. Female mouse germ cells form synchronously dividing cysts. Development 125: 3323-3328.

Pepling ME, Spradling AC. 2001. Mouse ovarian germ cell cysts undergo programmed breakdown to form primordial follicles. Dev Biol 234: 339-351.

Perea-Gomez A, Vella FD, Shawlot W, Oulad-Abdelghani M, Chazaud C, Meno C, Pfister V, Chen L, Robertson E, Hamada $\mathrm{H}$, et al. 2002. Nodal antagonists in the anterior visceral endoderm prevent the formation of multiple primitive streaks. Dev Cell 3: 745-756.

Ross A, Munger S, Capel B. 2007. Bmp7 regulates germ cell proliferation in mouse fetal gonads. Sex Dev 1: 127-137.

Ruggiu M, Speed R, Taggart M, McKay SJ, Kilanowski F, Saunders P, Dorin J, Cooke HJ. 1997. The mouse Dazla gene encodes a cytoplasmic protein essential for gametogenesis. Nature 389: 73-77.

Saba R, Kato Y, Saga Y. 2014a. NANOS2 promotes male germ cell development independent of meiosis suppression. Dev Biol 385: 32-40.

Saba R, Wu Q, Saga Y. 2014b. CYP26B1 promotes male germ cell differentiation by suppressing STRA8-dependent meiotic and STRA8-independent mitotic pathways. Dev Biol 389: 173-181.

Sada A, Suzuki A, Suzuki H, Saga Y. 2009. The RNA-binding protein NANOS2 is required to maintain murine spermatogonial stem cells. Science 325: 1394-1398. 
Saitou M, Miyauchi H. 2016. Gametogenesis from pluripotent stem cells. Cell Stem Cell 18: 721-735.

Saitou M, Yamaji M. 2012. Primordial germ cells in mice. Cold Spring Harb Perspect Biol 4: a008375.

Saitou M, Barton SC, Surani MA. 2002. A molecular programme for the specification of germ cell fate in mice. Nature 418: 293-300.

Sasaki K, Yokobayashi S, Nakamura T, Okamoto I, Yabuta Y, Kurimoto K, Ohta H, Moritoki Y, Iwatani C, Tsuchiya $\mathrm{H}$, et al. 2015. Robust in vitro induction of human germ cell fate from pluripotent stem cells. Cell Stem Cell 17: 178-194.

Sasaki K, Nakamura T, Okamoto I, Yabuta Y, Iwatani C, Tsuchiya H, Seita Y, Nakamura S, Shiraki N, Takakuwa T, et al. 2016. The germ cell fate of cynomolgus monkeys is specified in the nascent amnion. Dev Cell 39: 169-185.

Sato T, Katagiri K, Gohbara A, Inoue K, Ogonuki N, Ogura A, Kubota Y, Ogawa T. 2011. In vitro production of functional sperm in cultured neonatal mouse testes. Nature 471: 504 507.

Seisenberger S, Andrews S, Krueger F, Arand J, Walter J, Santos F, Popp C, Thienpont B, Dean W, Reik W. 2012. The dynamics of genome-wide DNA methylation reprogramming in mouse primordial germ cells. Mol Cell 48: 849-862.

Shirane K, Kurimoto K, Yabuta Y, Yamaji M, Satoh J, Ito S, Watanabe A, Hayashi K, Saitou M, Sasaki H. 2016. Global landscape and regulatory principles of DNA methylation reprogramming for germ cell specification by mouse pluripotent stem cells. Dev Cell 39: 87-103.

Sinclair AH, Berta P, Palmer MS, Hawkins JR, Griffiths BL, Smith MJ, Foster JW, Frischauf AM, Lovell-Badge R, Goodfellow PN. 1990. A gene from the human sex-determining region encodes a protein with homology to a conserved DNA-binding motif. Nature 346: 240-244.

Soh YQ, Junker JP, Gill ME, Mueller JL, van Oudenaarden A, Page DC. 2015. A gene regulatory program for meiotic prophase in the fetal ovary. PLoS Genet 11: e1005531.

Soh YQS, Mikedis MM, Kojima M, Godfrey AK, de Rooij DG, Page DC. 2017. Meioc maintains an extended meiotic prophase I in mice. PLoS Genet 13: e1006704.

Speed RM. 1982. Meiosis in the foetal mouse ovary. I. An analysis at the light microscope level using surface-spreading. Chromosoma 85: 427-437.

Spiller CM, Feng CW, Jackson A, Gillis AJ, Rolland AD, Looijenga LH, Koopman P, Bowles J. 2012. Endogenous Nodal signaling regulates germ cell potency during mammalian testis development. Development 139: 4123-4132.

Spiller C, Koopman P, Bowles J. 2017. Sex determination in the mammalian germline. Annu Rev Genet. doi: 10.1146/annurevgenet-120215-035449

Steinberger A, Steinberger E, Perloff WH. 1964. Mammalian testes in organ culture. Exp Cell Res 36: 19-27.

Suzuki A, Saga Y. 2008. Nanos2 suppresses meiosis and promotes male germ cell differentiation. Genes Dev 22: 430435.

Tang WW, Dietmann S, Irie N, Leitch HG, Floros VI, Bradshaw CR, Hackett JA, Chinnery PF, Surani MA. 2015. A unique gene regulatory network resets the human germline epigenome for development. Cell 161: 1453-1467.

Toshimori K, Eddy EM. 2015. The spermatozoon. In Knobil and Neill's physiology of reproduction (eds. Plant TM, Zeleznik AJ, Albertini DF, et al.), pp. 99-148. Elsevier/Academic, New York.

Ueda T, Abe K, Miura A, Yuzuriha M, Zubair M, Noguchi M, Niwa K, Kawase Y, Kono T, Matsuda Y, et al. 2000. The paternal methylation imprint of the mouse H19 locus is acquired in the gonocyte stage during foetal testis development. Genes Cells 5: 649-659.

Uhlenhaut NH, Jakob S, Anlag K, Eisenberger T, Sekido R, Kress J, Treier AC, Klugmann C, Klasen C, Holter NI, et al. 2009. Somatic sex reprogramming of adult ovaries to testes by FOXL2 ablation. Cell 139: 1130-1142.

Watanabe Y. 2012. Geometry and force behind kinetochore orientation: Lessons from meiosis. Nat Rev Mol Cell Biol 13: 370-382.

Wilkins AS, Holliday R. 2009. The evolution of meiosis from mitosis. Genetics 181: 3-12.

Wilson JG, Roth CB, Warkany J. 1953. An analysis of the syndrome of malformations induced by maternal vitamin A deficiency. Effects of restoration of vitamin A at various times during gestation. Am J Anat 92: 189-217.

Wu Q, Kanata K, Saba R, Deng CX, Hamada H, Saga Y. 2013. Nodal/activin signaling promotes male germ cell fate and suppresses female programming in somatic cells. Development 140: 291-300.

Wu Q, Fukuda K, Weinstein M, Graff JM, Saga Y. 2015. SMAD2 and p38 signaling pathways act in concert to determine XY primordial germ cell fate in mice. Development 142: 575-586.

Wu Q, Fukuda K, Kato Y, Zhou Z, Deng CX, Saga Y. 2016. Sexual fate change of XX germ cells caused by the deletion of SMAD4 and STRA8 independent of somatic sex reprogramming. PLoS Biol 14: e1002553.

Yao HH, Matzuk MM, Jorgez CJ, Menke DB, Page DC, Swain A, Capel B. 2004. Follistatin operates downstream of Wnt4 in mammalian ovary organogenesis. Dev Dyn 230: 210-215.

Yokobayashi S, Liang CY, Kohler H, Nestorov P, Liu Z, Vidal M, van Lohuizen M, Roloff TC, Peters AH. 2013. PRC1 coordinates timing of sexual differentiation of female primordial germ cells. Nature 495: 236-240.

Yoshida S. 2012. Elucidating the identity and behavior of spermatogenic stem cells in the mouse testis. Reproduction 144: 293-302.

Yoshida S, Sukeno M, Nakagawa T, Ohbo K, Nagamatsu G, Suda T, Nabeshima Y. 2006. The first round of mouse spermatogenesis is a distinctive program that lacks the self-renewing spermatogonia stage. Development 133: 1495-1505.

Zheng G, Dahl JA, Niu Y, Fedorcsak P, Huang CM, Li CJ, Vagbo CB, Shi Y, Wang WL, Song SH, et al. 2013. ALKBH5 is a mammalian RNA demethylase that impacts RNA metabolism and mouse fertility. Mol Cell 49: 18-29.

Zhou Q, Wang M, Yuan Y, Wang X, Fu R, Wan H, Xie M, Liu M, Guo X, Zheng Y, et al. 2016. Complete meiosis from embryonic stem cell-derived germ cells in vitro. Cell Stem Cell 18: $330-340$. 


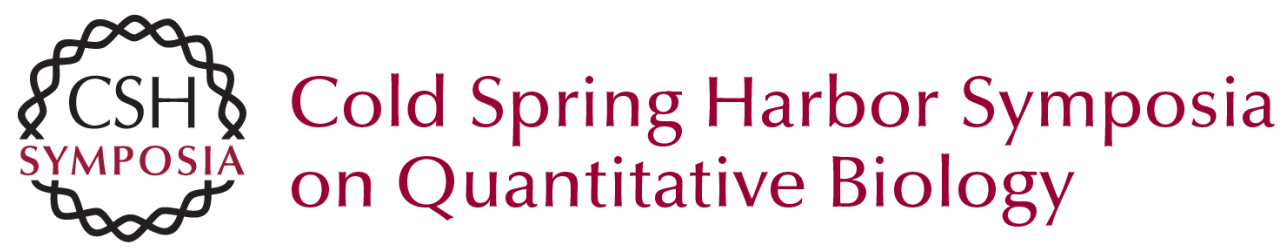

\section{Reconstitution of Female Germ Cell Fate Determination and Meiotic Initiation in Mammals}

So I. Nagaoka and Mitinori Saitou

Cold Spring Harb Symp Quant Biol 2017 82: 213-222 originally published online December 5, 2017

Access the most recent version at doi:10.1101/sqb.2017.82.033803

References This article cites 127 articles, 33 of which can be accessed free at: http://symposium.cshlp.org/content/82/213.full.html\#ref-list-1

Creative This article is distributed under the terms of the

Commons http://creativecommons.org/licenses/by-nc/4.0/, which permits reuse and

License redistribution, except for commercial purposes, provided that the original author and source are credited.

Email Alerting Receive free email alerts when new articles cite this article - sign up in Service the box at the top right corner of the article or click here. 